\title{
Pancreatic Hemorrhage
}

National Cancer Institute

\section{Source}

National Cancer Institute. Pancreatic Hemorrhage. NCI Thesaurus. Code C78521.

Bleeding originating from the pancreas. 